\title{
O território do qualquer outro e o exercício de um ethos quase impossível
}

\author{
The territory of any other and the exercise of an almost impossible ethos \\ El território de algún outro y el ejercicio de un ethos casi imposible
}

Recebido: 20/10/2021 | Revisado: 27/10/2021 | Aceito: 29/10/2021 | Publicado: 01/11/2021

Raphaela Rodrigues Mello de Castro Cunha

ORCID: https://orcid.org/0000-0002-8417-5558

Universidade Presbiteriana Mackenzie, Brasil

E-mail: ra_mello@hotmail.com

Igor Guatelli

ORCID: https://orcid.org/0000-0002-3937-8073

Universidade Presbiteriana Mackenzie, Brasil

E-mail: igorguatelli@gmail.com

\begin{abstract}
Resumo
No contexto capitalista neoliberal, o medo, reflexo dos permanentes e multiescalares processos de exclusão social, do desamparo do Estado, permeia o engendramento das próprias relações, solidificando-as em extratos. Nesse processo de estratificação, constrói barreiras nas quais o outro, a alteridade, é sinônimo de ameaça, perigo, alguém ou algo a ser evitado. Como resultado, acentua-se a polarização entre classes, crenças, etnias, ideologias, e, consequentemente, uma estruturação de interações homogêneas, uniformes, moldada a partir do pressuposto de que as diferenças devem ser reprimidas ou excluídas. Essa prática social favorece a emergência de indivíduos anempáticos, imunizados e, destrutivamente, autoimunizados. Propõe-se neste trabalho o entendimento do contexto urbano social da cidade de São Paulo por meio de revisão bibliográfica e a partir disso analisar, via objeto de estudo, como a Ocupação 9 de julho atua contrariamente a estes enclaves. Territorializados na cidade, muitas vezes, por meio de ocupações urbanas que buscam se posicionar de forma civil e urbana, são capazes de transmutações locais do cenário mundial; aqui, especificamente o da cidade de São Paulo.
\end{abstract}

Palavras-chave: Alteridade; Estruturações sociais; Interações; São Paulo; Ocupação 9 de julho.

\begin{abstract}
In the neoliberal capitalist context, the fear of the state's helplessness, as a reflection of the permanent and multi-scale processes of social exclusion, penetrates the development of relationships, solidifying them into extracts. In this stratification process, fear builds barriers in which an individual, the otherness, is a synonym of threat and danger: a someone or something to be avoided. As a result, there is an intensification of the polarization between classes, beliefs, ethnicities, ideologies. Therefore, it creates a uniform structure of interactions, based on the assumption that differences must be repressed or excluded. This social practice favors the emergence of anempathic, immune and, destructively, self-immune individuals. This work proposes the understanding of the urban social context of the city of São Paulo through a bibliographical review and, from this, analyzes, as an object of study, how the 9 de julho Occupation acts contrary to these enclaves. Territorialized in the city, often through urban occupations that seek to position themselves in a civil and urban way, they are capable of local transmutations on a world level; here, more specifically, the change of the scenery in São Paulo.
\end{abstract}

Keywords: Otherness; Social structures; Interactions; São Paulo; 9 de julho Occupation.

\section{Resumen}

En el contexto capitalista neoliberal, el miedo, reflejo de los procesos permanentes y de múltiples escalas de exclusión social, del desamparo del Estado, impregna la generación de sus propias relaciones, solidificandose en extractos. En este proceso de estratificación, construye barreras en las que el otro, la alteridad, es sinónimo de amenaza, peligro, alguien o algo a evitar. Como resultado, se acentúa la polarización entre clases, creencias, etnias, ideologías y, en consecuencia, una estructura de interacciones homogéneas y uniformes, moldeada a partir del supuesto de que las diferencias deben ser reprimidas o excluidas. Esta práctica social favorece la aparición de individuos anépticos, inmunizados y autoinmunizados destructivamente. Este trabajo propone la comprensión del contexto social urbano de la ciudad de San Pablo através de una revisión bibliográfica y, a partir de ella, analizar, vía objeto de estudio, como la Ocupación 9 de julio actúa contra de estos enclaves. Territorializados en la ciudad, muchas veces a través de ocupaciones urbanas que buscan posicionarse de manera civil y urbana, son capaces de transmutaciones locales en el escenario mundial; aquí, específicamente el de la ciudad de São Paulo.

Palabras clave: Alteridad; Estructuras sociales; Interacciones; San Pablo; Ocupación 9 de julio. 


\section{Introdução}

No período compreendido entre o final do século XX e início do século XXI, o filósofo francês Emmanuel Lévinas discorreu sobre a importância do alter, do outro humano, outro rosto, no desenvolvimento do Ser e do humanismo, que segundo o autor daria sentido ao homem na contemporaneidade, caracterizando-o como o "sentido [ético] dos sentidos" (Lévinas, 2009, p.40) do humano. A ótica deste pensamento propõe uma nova perspectiva ao "anti-humanismo" (Lévinas, 2009, p.88) do estruturalismo, tendo em vista a crença de Lévinas de que embora o sistema neoliberal contribua para a formação de uma sociedade individualista, autocentrada, através do encontro e interação tem-se a possibilidade de desenvolver-se a sensibilidade entre os indivíduos, concorrendo para o despertar dos sentimentos humanistas como fraternidade, empatia, respeito etc., presentes no que o autor acredita ser a essência do ser humano. "Nossa época não se define pelo triunfo da técnica pela técnica, como não se define através da arte pela arte, e nem se define pelo niilismo. Ela é ação por um mundo que vem, superação de sua época - superação de si que requer a epifania do Outro.” (Lévinas, 2009, p.46)

Considerado a notoriedade da ética da alteridade proposta por Lévinas, justifica-se estudar sua aplicabilidade frente ao cenário urbano paulistano. Para tal, primeiramente faz-se necessário um melhor entendimento deste contexto, que a priori que será suprido via revisão bibliográfica e complementado com um estudo de caso.

Traz-se como proposta de trabalho deste artigo uma reflexão sobre duas obras literárias que desenvolvem um pensamento elucidativo a respeito da dinâmica social e urbana presente na cidade de São Paulo. Como fonte de discussão sobre desenvolvimento da morfologia urbana da cidade de paulistana será avaliada a obra Cidadania insurgente: disjunções da democracia e da modernidade no Brasil, do autor James Holston; paralelamente, com o intuito de traçar um paralelo deste devir urbano e sua potencialidade de agente, e, ao mesmo tempo produto das dinâmicas sociais, a partir de uma perspectiva autobiográfica, elege-se como objeto de estudo a obra da escritora Carolina Maria de Jesus, autora do livro Quarto de Despejo: Diário de uma favelada, desenvolvido através do diário pessoal da autora, nos anos 60. A escolha de ambas as biografias devese ao fato de que as mesmas ilustram como o meio urbano paulista é fortemente marcado por trincheiras excludentes.

Dada a análise bibliográfica territorial e social, este artigo tem como objeto de estudo, ainda, as rupturas com o tempo/espaço tradicional, às quais Foucault chamou "heterocronias" - parcelas de tempo que proporciona uma ruptura tempoespaço tradicional, uma justaposição de acontecimentos em um mesmo local (Foucault, 1986) - presentes na Ocupação 9 de julho, na cidade de São Paulo. Assim, pretende-se evidenciar o quanto locais que proporcionam a possibilidade de interações sociais heterogêneas são essenciais para o desenvolvimento dessa sociedade.

\section{Metodologia}

Tendo em vista a complexidade da temática que envolve percepções e sensações, além de divagar sobre cenários fraternos, ideias, torna-se imprescindível a revisão bibliográfica como fonte primária e essencial do trabalho proposto. Com isso, elege-se a pesquisa qualitativa como embasamento para a elaboração das análises propostas por este trabalho.

Trata-se de um estudo de caso, tendo como objeto central a Ocupação 9 de julho. A partir da análise territorial, observatório e analítica, do que acontece atualmente na Ocupação 9 de julho, visa-se traçar um panorama teórico a fim de ratificar tais comportamentos, tal como, possibilitar novos entendimentos, possibilidades. A temática principal constatada no estudo de caso será ancorada na revisão de literatura, permitindo uma aproximação com o tema, desenvolvendo um panorama consistente que possibilita ao pesquisador vislumbrar oportunidades de pesquisa nos estudos organizacionais (Botelho, L.; Cunha, C.; Macedo, M., 2011).

A metodologia de estudo de caso foi eleita, tendo em vista a constatação real das fundamentações bibliográficas identificadas, indo de encontro com estruturas preconizadas por Yin (2001). "Portanto, o estudo de caso é um modo de se 
investigar um fenômeno empírico seguindo um conjunto de procedimentos pré-especificados e que pode ser utilizado, especialmente, com as seguintes finalidades" (Yin, 2001, p.34-35)

A partir da análise circunstancial objetiva, desenvolve-se um raciocínio teórico respaldado no embasamento literário; organiza-se então, de maneira sistemática, ordenada e abrangente o enfoque principal da temática: territorialização da alteridade, presente no estudo de caso da Ocupação 9 de julho. Ocorre, portanto, identificação do fenômeno particular; descrição do assunto submetido a indagação; explicação do como o estudo de caso ajuda a compreender o objeto de análise, construção de interpretações e perspectivas; correlação dos resultados obtidos [revisão e síntese do conhecimento produzido] sobre análise de estudo de caso.

A escolha literária foi categorizada de forma revisão bibliográfica integrativa, devido ao seu caráter abrangente. "Uma revisão integrativa é um método específico, que resume o passado da literatura empírica ou teórica, para fornecer uma compreensão mais abrangente de um fenômeno particular (Broome, 2006 apud Botelho, L.; Cunha, C.; Macedo, M., 2011). Foram avaliados: aplicabilidade do tema; critérios de inclusão, tendo em vista: importância histórica, período cronológico, representatividade, proximidade com objeto de estudo de caso; pré-seleção e seleção das obras; categorização [organização cronológica levando em consideração o panorama, tema, macro e seu afunilamento em direção ao objeto de estudo, micro]; análise e interpretação dos resultados; síntese do conhecimento; completando, portanto, a análise do objeto de estudo. "O método de revisão integrativa é uma abordagem que permite a inclusão de estudos que adotam diversas metodologias (ou seja, experimental e de pesquisa não experimental).” Botelho, L.; Cunha, C.; Macedo, M. (2011).

Para tal, foram estudados como principais referências o filósofo francês Lévinas, cuja obra explora a ética da alteridade; a escritora Maria Carolina de Jesus, com o intuito de expor o cenário urbano e social existente ainda hoje na cidade de São Paulo, e os teóricos David Harvey e James Holston; o filósofo Byung-Chul-Han, responsável por estabelecer uma análise sociológica crítica da sociedade contemporânea; e o sociólogo e historiador Richard Sennett, que desenvolve, contemporaneamente, uma filosofia muito similar à de Lévinas, tendo em vista que ambos os autores enfatizam a importância do outro na composição do todo, sendo, portanto complementares.

Por fim, objetiva-se constatar como a realidade da Ocupação 9 de julho, objeto de estudo de caso, se relaciona com as mudanças sociais anunciadas por esses atores.

\section{Resultados e Discussão}

Para o desenvolvimento da temática apresentada, há uma necessidade da fundamentação teórica que será sistematiza da seguinte forma: (i) sustentação teórica sobre a relevância do desenvolvimento da alteridade no contexto urbano; (ii) uma breve contextualização quanto à segregação territorial e urbana, (iii) entendimento das insurgências, processos eruptivos resultantes da desigualdade social, e também fontes de novas possibilidades e cenários, (iv) objeto de estudo: Ocupação 9 de julho e sua importância na contribuição do contexto urbano paulista.

\subsection{A ética da alteridade}

Ao nos depararmos com a vida comunitária, um ambiente com relações interligadas, pode-se refletir sobre o quanto o outro compõe nossa identidade, valores e ações. Em suas obras, Lévinas explica essa sensibilidade através do que ele denominou "ética da alteridade", que é atrelada à responsabilidade que temos diante de outro ser humano, a intersubjetividade. Para ele, a ética é fundamentada a partir dessas relações e trocas, e o principal elo entre os indivíduos está justamente no fato de se constatarem demasiadamente humanos, ou seja, sensíveis às fragilidades do outro, essência do que poderíamos denominar o humanismo contemporâneo. 
O humanismo significa o reconhecimento de uma essência invariável denominada "homem"; afirmação de seu lugar central na economia do Real e de seu valor que engendra todos os valores: respeito da pessoa que há em si [sujeito] e no outro, a exigir a salvaguarda da [sua] Liberdade; Significa também expansão da natureza humana: da inteligência na Ciência, da criação na Arte, do prazer na vida cotidiana; da satisfação dos desejos, sem prejuízo para a Liberdade e para os prazeres dos outros e consequentemente se traduz na instauração de uma Lei justa, isto é, de um Estado razoável e Liberal e, por antomásia, um Estado em paz com outros, inaugurando - esse é um ponto a ressaltar - para os indivíduos um domínio vasto no âmbito do privado bem no limiar do qual a Lei cessa, se paralisa. Um limite à Lei é essencial ao humanismo. Pois, o humanismo não pensa, talvez, em outras leis, senão àquelas advindas do Estado e da Natureza. (Lévinas, 1990, p.385 apud Ribeiro Junior, 2019, p.27)

Na obra Os tempos hipermodernos o autor Gilles Lipovetsky (2004) discorre sobre o quanto as redes sociais, o consumismo e as "relações de poder" (Foucault, 1999 apud Ferreirinha; Raitz, 2010) constituem o cenário contemporâneo, no qual a cultura e os comportamentos estão fundamentados a partir da subjetividade, inflação do ego, do prisma subjetivo, acarretando o distanciamento do alter, o seu apagamento. O dilema das redes contido no pensamento de Lipovetsky vai ao encontro da reflexão de Lévinas, que faz uma análise crítica existencial sobre o risco de um possível encantamento poético do indivíduo sobre si mesmo. Quando acentuado, o deslumbre perante a autoimagem repercute de forma negativa, produzindo indivíduos autocentrados, que ignoram a importância da alteridade/linguagem como agentes estimuladores e interlocutores desta jornada de desenvolvimento do ser, a essência do bem na ética. Portanto, pode-se afirmar que o "alter" é uma provocação constituinte do "ente", e é fundamental para o desenvolvimento do indivíduo. "Ora, a magia ou a sedução do discurso evolui de um pensamento totalitário, violento. Essa magia não apenas é sinônimo da absoluta indiferença ao diferente outrem e ao desprezo da alteridade irredutível do outro, mas efetiva ou instaura a catástrofe de uma política destinada ao extermínio do rosto.” (Lévinas, 1990, p.385 apud Ribeiro Junior, 2019, p.5)

Frente ao padrão social atual, onde redes virtuais ganham mais destaques e os grupos sociais se estratificam, o encontro é o espaço temporal que possibilita o sentimento de epifania do rosto - entende-se como epifania do rosto à sensibilidade e estímulo provocado pelo alter através do rosto (Lévinas, 2011) - como também, a possibilidade de interação e o surgimento do questionamento moral e social, podendo instigar a consciência de obrigações mútuas.

Segundo Lévinas (2011), ao construirmos uma sociedade na qual seus cidadãos têm responsabilidade uns para com os outros, pode-se estimular ações solidárias, diminuir desigualdades, injustiças etc.

Contudo, pode-se argumentar que a grande dificuldade da quebra dos paradigmas sociais está na segregação urbana, pois o entrincheiramento endógeno (é possível entender as ocupações como entrincheiramentos exógenos, voltados ao de fora) dificulta a convivência entre diferentes grupos sociais, potencializando o sentimento de "nós" vs. "eles". A principal questão desta "antinomia" alimentada pelo sistema capitalista está na fragilidade de sustentar a possibilidade da construção de uma sociedade baseada no compartilhamento como força vital de sua própria constituição.

Valores e ações que têm tal fim como pressuposto, muitas vezes são desacreditados e rotulados como utópicos, irreais e inexequíveis. Ainda que isso possa ser verdade, vale ressaltar que, não a utopia em si, mas seu exercício, pode nos alavancar e atuar como bússola de um caminho, mesmo com um por vir impossível.

\subsection{A cidade e as minorias}

A cidade, urbes, é o principal palco dos encontros e conflitos comunitários e tem extrema importância na desmistificação dos estigmas sociais. O teórico David Harvey, ao longo de sua obra, analisou a complexidade das relações desenvolvidas no contexto urbano, tal como sua capacidade de produção de populações vulneráveis clamando por justiça social, originando o que foi denominado por ele como "cidades rebeldes" (Harvey, 2014). Diante da vivacidade urbana presente na obra de Harvey e seus desdobramentos, pode-se constatar que a morfologia e estruturação demonstram-se como potentes modeladores sociais. "A cidade sempre foi um lugar de encontro, de diferença e de interação criativa, um lugar onde a 
desordem tem seus usos e visões, formas culturais e desejos individuais concorrentes se chocam. Mas a diferença também pode resultar em intolerância e segregações, marginalidade e exclusão, quando não em fervorosos confrontos.” (Harvey, 2013, p.30)

Analisando o panorama da cidade de São Paulo, conseguimos identificar visualmente e empiricamente as mazelas da estruturação urbana paulistana, que pode ser considerada desigual, racista e falogocêntrica - compreende-se como falogocêntrica a prevalência e superioridade masculina na construção da razão e cultura indo-europeia e sua difusão para o mundo ocidental (Dely, 2011). Pretendendo um melhor entendimento frente a realidade vivida pelos que carregam em si os efeitos de uma nação desigual e estigmatizada, é interessante considerar aqui os diários de Carolina Maria de Jesus, publicados sob o título Quarto de despejo: diário de uma favelada, em 1960.

O livro relata a vivência de uma mulher preta, pobre, mãe solteira, favelada e semianalfabeta, que vive na marginal Tietê, em São Paulo, na favela do Canindé, entre os anos de 1955 e 1960. A narrativa descreve um cenário marcado pela miséria, a luta diária pela sobrevivência, rodeado pela violência, alcoolismo, patriarcado, descompromisso social por parte do Estado, preconceitos, falta de acesso a serviços públicos essenciais e exclusão social. No trecho abaixo, identifica-se a violência presente no cotidiano da autora, relações de abusos suscitados pelo machismo e desinformação. "A noite enquanto elas pede socorro, eu tranquilamente no meu barracão ouço valsas vienenses. Enquanto os esposos quebra as tabuas do barracão eu e meus filhos dormimos sossegados. Não invejo as mulheres casadas da favela que levam vida de escravas indianas." (Jesus, 1960, p.17)

Segundo Carolina Maria de Jesus (1960), na favela há expressiva presença de negros, nordestinos e imigrantes. Investigando a formação urbana da cidade de São Paulo, constata-se que essa parcela da população que constitui maioria quantitativa é que compõe a minoria, sob o aspecto dos direitos conquistados e a representatividade: “... Nas prisões os negros eram os bodes expiatórios." (Jesus, 1960, p.30)

No livro, a favela é retratada como um local extremamente negativo, hostil e segregado, e já se vislumbra a necessidade das massas de se sentirem representadas por políticos que conversem mais com a sua realidade, que os representem.

Quando estou na cidade tenho a impressão que estou na sala de visita com seus lustres de cristais, seus tapetes de veludos, almofadas de sitim. E quando estou na favela tenho a impressão que sou um objeto fora de uso, digno de estar num quarto de despejo. [...] Quem governa o nosso país é quem tem dinheiro, quem não sabe o que é fome, a dor, e aflição do pobre. Se a maioria revoltar-se, o que pode fazer a minoria? Eu estou ao lado do pobre, que é o braço. Braço desnutrido. Precisamos livrar o paiz dos políticos açambarcadores. (Jesus, 1960, p.37; 39)

A realidade descrita pela autora nos anos 60 ainda hoje retrata o cotidiano de muitos brasileiros, que lidam diariamente com a incerteza de um futuro, dificuldades de acessos e insegurança alimentar. Traz-se como proposta, em prol da construção de um cenário mais fraterno e menos violento, a introdução do encontro entre indivíduos, como ferramenta da desistigmatização do alter e, portanto, de atenuação das mazelas sociais. A responsabilidade pelo alter, por meio do envolvimento entre partes, até então estigmatizadas, visa mitigar a insegurança existencial e estrutural, ao qual todos estamos submetidos, tendo como objetivo transcendê-la, e, a partir do encontro, visualizar e compreender o que até então era imperceptível.

\subsection{A insurgência}

A favela, descrita por Carolina Maria de Jesus, foi se modificando ao longo do tempo. Ainda hoje existem na cidade de São Paulo espaços como os descritos pela autora. Entretanto, a periferia foi se tornando cada vez mais complexa, 
especialmente devido à sua capacidade adaptativa e evolutiva: "Quando passaram a construir e montar suas casas, as classes trabalhadoras assumiram as identidades sem precedentes de produtores e consumidores da vida urbana." (Holston, 2013, p.27)

Muitos espaços denominados periféricos já foram incorporados ao contexto urbano e o perfil de seus cidadãos vem se modificando por meio de um crescente empoderamento social e político. No livro Cidadania insurgente: Disjunções da democracia e da modernidade no Brasil, de 2013, James Holston constrói progressivamente o embasamento histórico e ideológico dessas comunidades. A obra traz um olhar tanto morfológico quanto sociológico, fazendo recortes históricos, no bojo dos quais realiza uma proposição a partir da qual o contexto urbano se apresenta como reflexo dos indivíduos que nele convivem. "Dessa forma, a autoconstrução transformou as periferias em espaços de futuro alternativo, produzidos nas experiências de se tornarem proprietários, de organizar movimentos sociais, de participar de mercados consumidores e de fazer julgamentos estéticos sobre as transformações das casas." (Holston, 2013, p.29)

A metamorfose dessas comunidades acarretou a modificação no perfil político brasileiro devido à potencialidade de transformação e apropriação, aos avanços atrelados a acessos educacionais e financeiros, uma legislação mais inclusiva, garantia de direitos trabalhistas e melhoria nos programas assistenciais: “... as classes trabalhadoras, integrantes dessas classes se tornaram novos cidadãos, não por meio de lutas trabalhistas, mas pelas lutas pela cidade...” (Holston, 2013, p.62)

Evidenciam-se, na cidade de São Paulo, uma crescente participação política, urbana e o empoderamento civil via comunidades insurgentes, constituídas principalmente pela classe trabalhadora, em sua maioria de baixa renda. Estigmatizados, marginalizados e oprimidos, mediante a organização e conscientização, transcendem os obstáculos estabelecidos, propondo uma nova maneira de apropriação dos direitos civis e humanos.

A corrente de habitações, advindas dos movimentos sociais, denominadas comunidades insurgentes é um dos meios pelos quais a referida população reivindica ações políticas e sociais, objetivando a construção de uma cidade e sociedade acessível e justa, e, ao mesmo tempo, construindo um ambiente propício ao debate político. O que acontece hoje na cidade de São Paulo é decorrente de séculos de opressão, mas também de um "despertar" social reivindicando direitos e estruturando mudanças. "A insurgência define um processo que é uma ação na contramão, uma contrapolítica, que desestabiliza o presente e o torna frágil, desfamiliarizando a coerência com que geralmente se apresenta. Insurgência não é imposição de cima para baixo de um futuro já orquestrado. Ela borbulha do passado em lugares onde as circunstâncias presentes parecem propícias a uma irrupção.” (Holston, 2013, p.62)

O filósofo contemporâneo sul-coreano, naturalizado alemão, Byung-Chul Han, nos anos 2017 e 2018, lançou uma coletânea de obras, cujo os títulos remetem a reflexão a respeito do período crítico em que estamos vivendo. Dentre eles está o título Sociedade da Transparência e Sociedade do Cansaço. Na obra, o autor interpela a fragilidade de nossas relações e ações políticas que ecoam por um cenário ilusório, de boas aparências, e, como a aceleração dos processos por meio da tecnologia e mídias contribuem para uma falta de narrativa e inconsistência de discursos. Segundo Han (2017), "o agir ocasiona ativamente novos processos. O homem moderno, ao contrário estaria passivamente exposto ao processo anônimo da vida." (Han, 2017, p.41)

As comunidades insurgentes são reação, e, igualmente resultado; uma revolução dos paradigmas sociais enraizados, preconizada pela conquista de direitos, através da habitação e do ambiente social no qual seus colaboradores passam a coexistir, pelo que se pode observar que as problemáticas brasileiras da desigualdade social e do racismo, originadas no sistema de plantation aliadas à possibilidade de apropriação de direitos, constituem uma fusão de grande potencial de transformação de realidade. 


\subsection{Ocupação 9 de julho}

Atualmente, há uma grande concentração de ocupações em imóveis abandonados, no centro da cidade de São Paulo. Pode-se considerar que essa apropriação territorial é produto direto da negação de direitos fundamentais, como a moradia. Ademais, pondera-se que a territorialização é impulsionada pelo movimento de reivindicação por direitos civis e urbanos, descrito por Holston (2013) como cidadania insurgente, e caracteriza, portanto, as ocupações como um movimento insurgente.

É importante esclarecer que a intervenção urbana proposta por algumas ocupações transcende a atribuição de um novo uso para o espaço. Os movimentos sociais buscam ver atendidas suas necessidades básicas de inserção/inclusão social, tais como, desenvolvimento dos seus indivíduos, despertar o sentimento de comunidade, modificação/conscientização social e reformas nos espaços físicos e urbanos de áreas abandonadas.

Sob o prisma neoliberal, verifica-se que um dos principais obstáculos aos movimentos sociais pró-moradia é o preconceito. A sacralização da propriedade privada e a supervalorização da meritocracia são a principal ancoragem de discursos reacionários que visam desqualificar os movimentos pelo direito à moradia. Sob a perspectiva de que as políticas públicas também são reflexo da opinião pública, muitos movimentos estão atuando fortemente na difusão de informação, abrindo suas portas à comunidade.

Em busca de compreender novas propostas de interação social, elege-se como estudo de caso a Ocupação 9 de julho, coordenada por Carmen Silva (2021), líder do movimento MSTC (Movimento dos Sem-teto do Centro). A escolha é decorrente da excepcionalidade que a ocupação representa com suas novas possibilidades de existência e resistência, atributo esse que instiga a curiosidade e a alteridade, permitidas com convites de participação ativa, voltados à sociedade, vide exemplo Figura 1, que retrata uma oficina de cartazes, realizada com a participação de moradores da Ocupação 9 de julho e indivíduos da comunidade, frequentadores da ocupação. Em meio a estes eventos, busca-se, através de movimentos como esse, construir uma ruptura com o tempo/espaço tradicional, denominada, por Foucault (1986), heterotopias. "Do outro espectro estão as heterotopias que estão associadas ao tempo na sua vertente mais fugaz, transitória, passageira. Refiro-me ao que assume o modo do festival. Estas heterotopias não estão orientadas para o eterno; bem pelo contrário, são de uma absoluta cronicidade, são temporais." (Foucault, 1986, p.6)

Figura 1 - Ocupação 9 de julho: lugar de outras tessituras sociais.

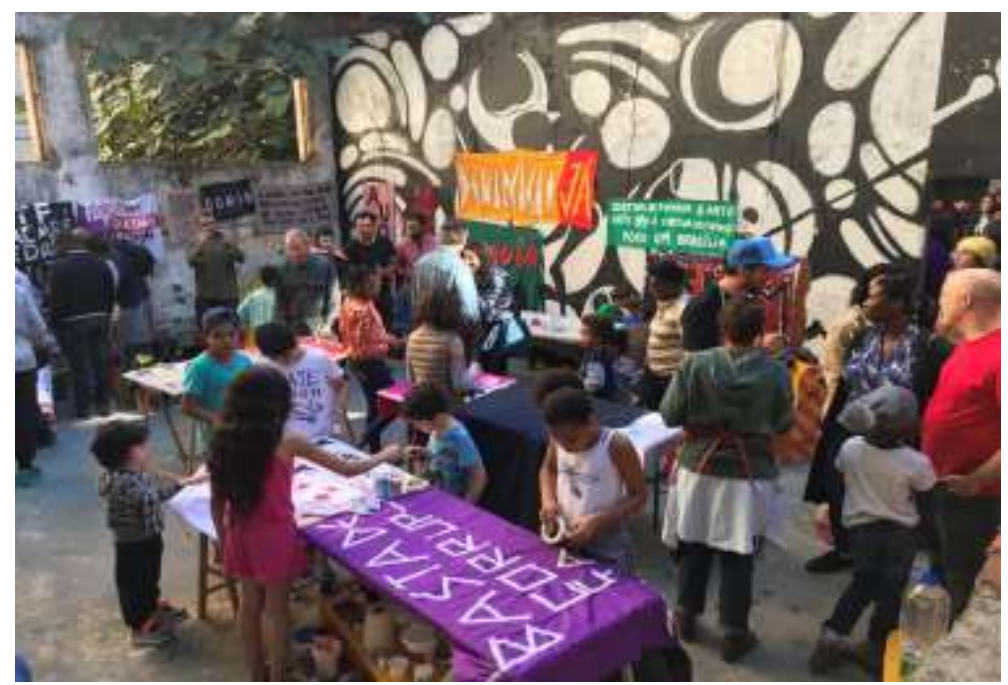

Fonte: Foto do Autor, acervo pessoal (2018). 
A Ocupação 9 de julho está é situada um edifício pertencente ao estilo Art déco localizada na Rua Álvaro de Carvalho, $n^{\circ} 427$, na região central da cidade de São Paulo, no edifício que foi a antiga sede do INSS. O edifício, que já passou por muitos usos, atualmente abriga uma ocupação do movimento MSTC, acolhendo hoje mais de 400 pessoas, e é reconhecido no contexto paulistano por sua capacidade de abertura à cidade. Nela são realizados eventos sociais e políticos, parcerias com universidades paulistanas, oficinas de desenvolvimento destinadas aos seus moradores, além do seu famoso almoço quinzenal que convida todo o público a experienciar a ocupação e conviver com seus moradores.

A respeito da utilização do local nos momentos entendidos como heterotopias, vislumbra-se que essas iniciativas ao mesmo tempo possibilitam encontros e trocas de ideias e experiências heterogêneas, tendo em vista que diferentes classes sociais, ainda que por um período, frequentam o mesmo espaço, vide exemplo concreto que retrata festa junina comunitária, Figura 2.

Figura 2 - Ocupação 9 de julho: o território das festas como lugar da desidentificação como possibilidade de quaisquer outras identificações.

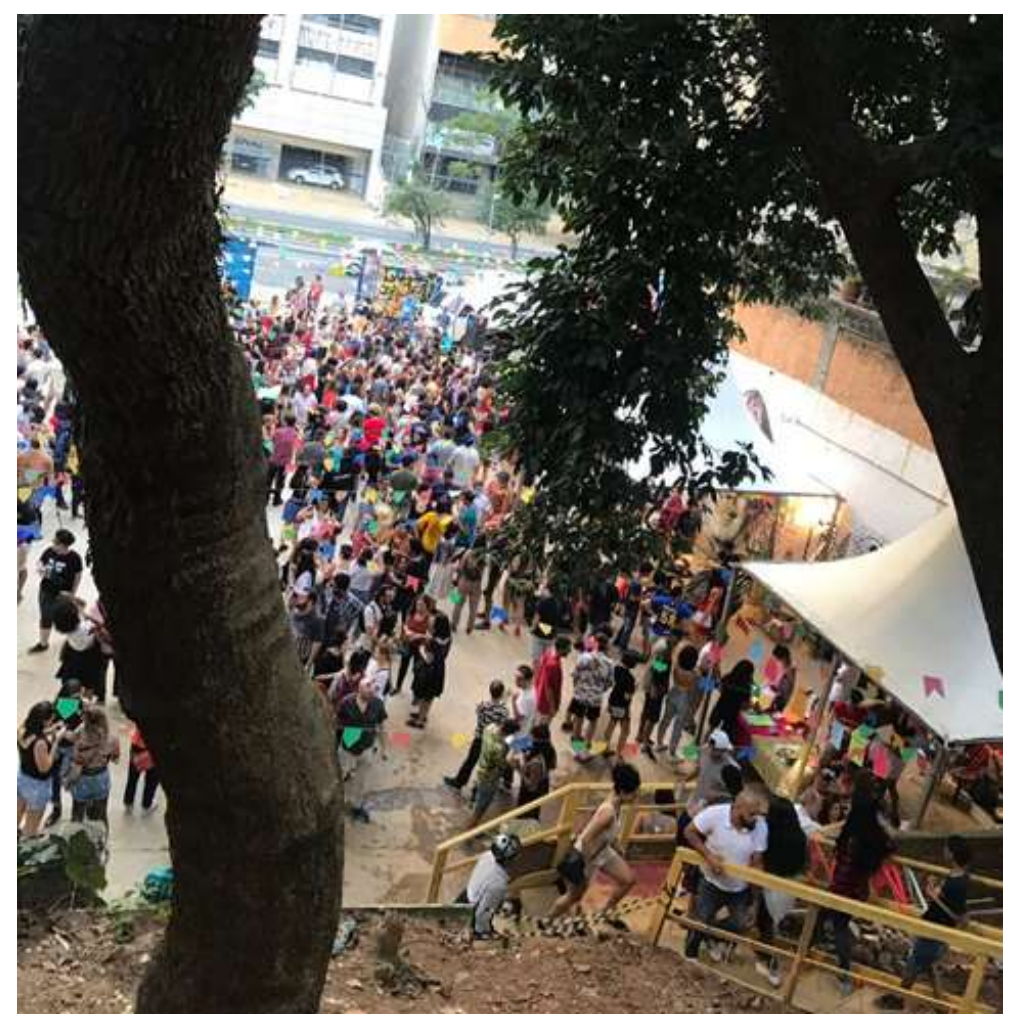

Fonte: Foto do Autor, acervo pessoal (2019).

Almoços, eventos e ações sociais são promovidos com intuito de quebrar paradigmas, possibilitando o convívio entre diferentes indivíduos, indo de encontro com a proposta de Sennett (2012). "A sensação de que somos diferentes de outra pessoa se desfaz com o tempo; se bebermos ou jantarmos com ela vinte vezes, esse tipo de estímulo provavelmente desaparecerá." (Sennett, 2012, p.104)

Tendo em vista a possibilidade do desenvolvimento da alteridade, entende-se que a proatividade da Ocupação 9 de julho atua de maneira ativa no contexto urbano, sendo essa atuante como conector ou ponte entre indivíduos de distintos grupos sociais. Pode-se sugerir que a aderência comunitária promovida nessas ações possibilita que o movimento seja avaliado como positivo, proporcionando também o maior engajamento da comunidade frente às pautas sociais, ou seja, acaba-se 
construindo um cenário propício ao entendimento e ao acolhimento, permitindo assim que sejam desmantelados os escudos, proteções e barreiras, dentre os indivíduos.

Compreende-se que o sentimento de pertencimento desenvolvido na vivência das ocupações, como por exemplo na Ocupação 9 de julho, promove uma formação de senso coletivo de responsabilidade e direitos mútuos. Este pensamento vai ao encontro da proposta de Lévinas no tocante à ética da alteridade, como também se relaciona com a noção de cooperatividade instigada por Richard Sennett (2012).

Outra possibilidade oferecida dentro da Ocupação 9 de julho é do exercício de uma razão dialógica, incentivando a construção de um cenário urbano e social a partir da união de esforços heterogêneos e díspares. Segundo Sennett (2012), a cooperação e a troca são instrumentos pelo qual podemos construir um cenário harmonioso. Sennett propõe a valorização de nossas diferenças como fonte de impulsão e possibilidades: "A conversa dialógica, como vimos, prospera através da empatia, o sentimento de curiosidade sobre os outros e o que são realmente". (Sennett, 2012, p. 34)

Ainda sobre a análise dialógica, pode-se tratar sobre a ação da conversa, tendo em vista que, para uma conversa, ainda que singela, faz-se exposta a face. O rosto impresso, na teoria de Lévinas atua como abertura ao outro, é instrumento agente e construtor. A possibilidade de interação heterogênea, entre indivíduos diferentes coexistindo em um mesmo ambiente, constitui uma potencialidade, tendo em vista a construção mútua dede um cenário comum. Salta aos olhos a proposta de construção conjunta de uma nova realidade urbana, e, nesse sentido, são inúmeras as possibilidades e alternativas para o futuro: "a cooperação antecede a individuação: ela é o fundamento do desenvolvimento humano, na medida em que aprendemos como estar juntos antes de aprender como nos manter à parte”. (Sennett, 2012, p. 24)

Contudo, entende-se que a reivindicação por uma cidade mais fluída, conectada e cosmopolita - leia-se englobando diferentes povos e crenças - que promova a inclusão, voltada ao bem-estar comum e contribui para que as relações sociais sejam ampliadas em suas expectativas e horizontes, o que, por sua vez, modifica o indivíduo, a comunidade, as residências e as relações pessoais. "Na experiência, encontramos o outro. Esses encontros são transformadores sim, nos modificam." (Han, 2017, p.84)

\section{Conclusão}

Pondera-se que as segregações territoriais solidificam o abismo social devido à sua incapacidade de promover o encontro e o convívio, portanto, mostrando-se incapaz de construir um panorama mais fraterno e pluralista. Através da análise das obras de Holston (2013) e Jesus (1960), constata-se barreiras existentes no meio urbano, bem como ficam evidentes os seus malefícios. O distanciamento resultante desse afastamento contribui para que os indivíduos entrem em um processo de auto imunização - leia-se processos de interiorização aplicado na vida urbana, no qual ocorre a autoimunização de preservação de lógicas diferenciais (Sloterdijk, 2014 apud Guatelli, 2020) - contra tudo que não lhes representa, aglutinando-se por semelhança, construindo ilhas imunes às interações homogêneas, onde a provocação e o apelo inesperado do outro tornam-se exceção.

Como negação à hipótese de existência de um processo previsto e pré-estabelecido, emergem novas possiblidades a partir das iniciativas de insurgência. As ocupações urbanas provenientes de movimentos insurgentes podem atuar com um viés de inclusão, sendo exemplo disso as ações da Ocupação 9 de julho, tendo em vista que nela verifica-se a possibilidade de desestigmatização do alter via epifania do rosto, ocasionada a partir do encontro. Sendo assim, Ocupação 9 de julho, viabiliza uma situação na "urbes" que proporciona experiências de troca, promove o afloramento de um senso de responsabilidade ética, e, por fim, contribui para o devir urbano, visão preconizada por relevantes autores do século XX e XXI, tais como Richard Sennett e Byung-Chul Han, aqui considerados. 
Em suma, a Ocupação 9 de julho, por meio da sua abertura à comunidade, propõe a destruição de fronteiras e arquétipos sociais, carregando a possibilidade de construção de locais apropriados para as dinâmicas de interação entre diferentes indivíduos. Nesses momentos, proporcionam-se encontros e possíveis trocas, tendo em vista que diferentes classes sociais, ainda que por um período, frequentam este espaço, concorrendo para o desenvolvimento de uma realidade dialógica por dialógica entende-se o desprendimento do compromisso em busco de um denominador, campo, comum, um local onde a troca e a experiência do outro são produto central de valorização (Sennett, 2012) - entre cidadãos, ratificando o quanto é rica a diversidade social e convergindo diretamente com a proposta de ética da alteridade presente no pensamento de Lévinas.

Por fim, locais urbanos onde há interação entre indivíduos possibilitam, além de experimentos sociais e urbanos, a concretização de um local frutífero, no que diz respeito à troca, desenvolvimento de novas percepções e ideias. Vislumbra-se que a exploração científica deste fenômeno possa ocorrer em inúmeras esferas em continuação com a temática aqui destrinchada, como por exemplo, a potencialidade deste contexto em outros cenários urbanos.

\section{Referências}

Botelho, L.; Cunha, C.; Macedo, M. O método da revisão integrativa nos estudos organizacionais. Gestão E Sociedade, Belo Horizonte-MG.121-136. Maio/Agosto. 2011. https://doi.org/10.21171/ges.v5i11.1220

Broome, M. E. Integrative literatura reviews for the development of concepts. In: Rodgers, B. L.; Castro, A. Revisão sistemática e meta-análise. 2006. https://www.metodologia.org/meta1.PDF

Dely, C. (2011). Jacques Derrida: El "Quizás" de un advenimiento de la otra-mujer. La deconstrucción del falogocentrismo del duelo al dúo. Instantes y Azares: Escrituras Nietzscheanas, 9, 77-93.

Ferreirinha, I. M. N.; Raitz, T. R. (2010). As relações de poder em Michel Foucault: reflexões teóricas. Revista de Administração Pública, v. 44, n. 2 , 367-383.

Foucault, M. (1986). De outros espaços: Conferência proferida por Michel Foucault no Cercle d'Études Architecturales, em 14 de Março de 1967. (Moura, P., Trad.) Diacritics, Baltimore, 16(1). (Trabalho original publicado em 1967)

Guatelli, I. (2020). Morar na abertura de interioridades. V!RUS, 20. http://www.nomads.usp.br/virus/virus20/?sec=5\&item=111\&lang=pt

Han, B.-C. (2015). Sociedade do cansaço. Petrópolis: Editora Vozes Limitada.

Han, B.-C. (2017). Sociedade da transparência. Petrópolis: Editora Vozes Limitada.

Harvey, D. (2013). A liberdade da cidade. In S. Zizek, D. Harvey, M. Davis, R. Rolnik, E. Maricato, J. S. Maior ... \& R. Schwarz. Cidades rebeldes: Passe livre e as manifestações que tomaram as ruas do Brasil (pp.26-34). São Paulo: Boitempo.

Harvey, D. (2014). Cidades rebeldes: do direito à cidade à revolução urbana. São Paulo: Martins Fontes.

Holston, J. (2013). Cidadania insurgente: disjunções da democracia e da modernidade no Brasil. São Paulo: Companhia das Letras.

Jesus, C. M. de. (1960). Quarto de despejo: diário de uma favelada. São Paulo: Francisco Alves.

Lévinas, E. (1990). Difficile Liberté. Livre de Poche. Paris: Albin Michel.

Lévinas, E. (2009). Humanismo do outro homem. Petrópolis: Vozes.

Lévinas, E. (2011). De outro modo que ser ou para lá da essência. Lisboa: Editora Centro de Filosofia da Universidade de Lisboa.

Lipovetsky, G. (2004). Os tempos hipermodernos (Vilela, M. Trad.). São Paulo: Editora Barcarolla. (Trabalho original publicado em 1944)

Ribeiro Júnior, N. (2019). O humanismo do outro homem: a ética como ótica e a sabedoria do amor em Lévinas [Seminário]. In Anais do Simpósio Internacional Filosófico-Teológico, 15, 23-45, XV Simpósio Internacional Filosófico-Teológico, Faculdade Jesuíta de Filosofia e Teologia, Belo Horizonte.

Sennet, R. (2012). Juntos. Barcelona: Anagrama.

Sloterdijk, P. (2014). Esferas III: Espumas - Esferología plural. Madri: Ediciones Siruela.

Yin, R. K. (2001). Estudo de caso: planejamento e método. (2a ed). Bookman. 